Beyond Machismo 
Chicana Matters Series

Deena 7. González and Antonia Castañeda, series editors

Chicana Matters Series focuses on one of the largest population groups in the United States today, documenting the lives, values, philosophies, and artistry of contemporary Chicanas. Books in this series may be richly diverse, reflecting the experiences of Chicanas themselves, and incorporating a broad spectrum of topics and fields of inquiry. Cumulatively, the books represent the leading knowledge and scholarship in a significant and growing field of research and, along with the literary works, art, and activism of Chicanas, underscore their significance in the history and culture of the United States. 


\section{Beyond Machismo}

Intersectional Latino Masculinities

AÍDA HURTADO AND MRINAL SINHA

University of Texas Press $\mathbf{v}$ Austin 
Copyright $\odot 2016$ by the University of Texas Press

All rights reserved

Printed in the United States of America

First edition, 2016

All illustrations courtesy of the authors

Excerpt from "Now Let Us Shift ... The Path of Conocimiento ... Inner Work, Public Acts," by Gloria Anzaldúa, in This Bridge We Call Home: Radical Visions for Transformation, edited by Gloria E. Anzaldúa and AnaLouise Keating, ๑ 2002 by Gloria E. Anzaldúa and AnaLouise Keating. Reproduced by permission of Taylor and Francis Group, LLC, a division of Informa plc.

Requests for permission to reproduce material from this work should be sent to:

Permissions

University of Texas Press

P.O. Box 7819

Austin, TX 78713-7819

www.utexas.edu/utpress/about/bpermission.html

(0) The paper used in this book meets the minimum requirements of ANSI/NISO Z39.48-1992 (R1997) (Permanence of Paper).

\section{Library of Congress Cataloging-in-Publication Data}

Hurtado, Aída, author.

Beyond machismo : intersectional Latino masculinities / Aída Hurtado and Mrinal Sinha. - First edition.

pages $\quad \mathrm{cm}-$ (Chicana matters series)

Includes bibliographical references and index.

ISBN 978-1-4773-0876-9 (cloth : alk. paper) -

ISBN 978-1-4773-0877-6 (pbk. : alk. paper) -

ISBN 978-1-4773-0878-3 (library e-book) -

ISBN 978-1-4773-0879-0 (nonlibrary e-book)

1. Men-Latin America-Identity. 2. Machismo-Latin America.

3. Masculinity-Social aspects-Latin America. 4. Men-Latin AmericaSocial conditions. 5. Men-Latin America-Economic conditions. 6. MenEducation-Latin America. 7. Feminism-United States. 8. Mexican American women-Ethnic identity. I. Sinha, Mrinal, author. II. Title. III. Series:

Chicana matters series.

HQ1090.7.L29H87 2016

$305.31098-\mathrm{dc} 23$

2015029050 


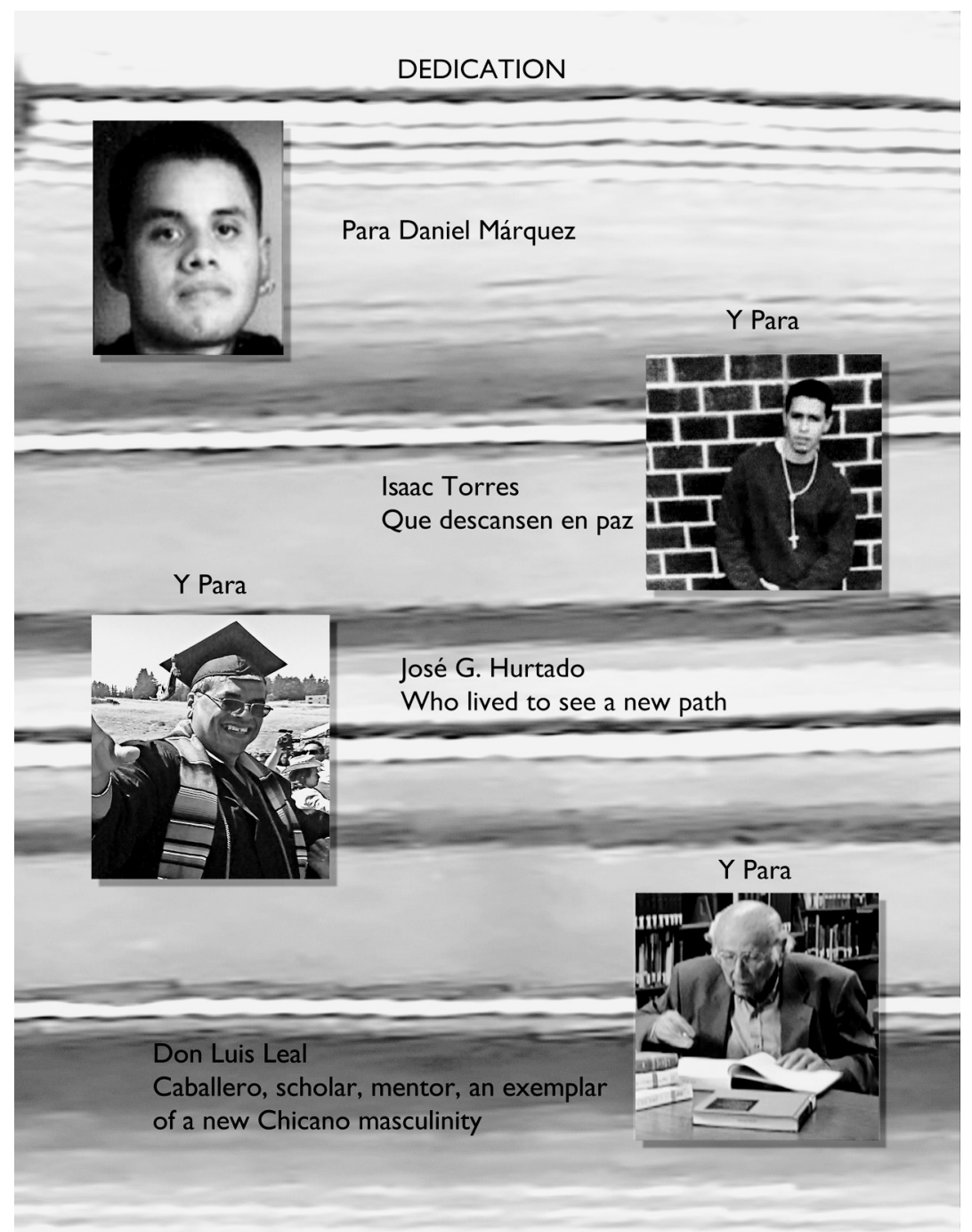


THIS PAGE INTENTIONALLY LEFT BLANK 